Conclusions Non-eosinophilic COPD subjects have more exacerbations, with more co-morbidities and bacterial burden (see Figure 1). Further work is required to understand the pathogenesis of this phenotype.

\section{P120 REAL LIFE DISTRIBUTION OF COPD SEVERITY IN THE GERMAN DACCORD REGISTRY: LUNG FUNCTION IS THE MAIN DRIVER OF CLASSIFICATION IN GOLD GROUP C AND D}

${ }^{1} \mathrm{H}$ Worth, ${ }^{2} \mathrm{R}$ Buhl, ${ }^{3} \mathrm{C}-\mathrm{P}$ Criee,,${ }^{1} \mathrm{P}$ Kardos, ${ }^{4} \mathrm{C}$ Mailaender, ${ }^{5} \mathrm{CF}$ Vogelmeier. ${ }^{1}$ Facharztforum Fuerth, Fuerth, Germany; ${ }^{2}$ Pulmonary Department, Mainz University Hospital, Mainz, Germany; ${ }^{3}$ Department of Sleep and Respiratory Medicine, Evangelical Hospital GoettingenWeende, Bovenden, Germany; ${ }^{4}$ Novartis Pharma GmbH, Nuermberg, Germany; ${ }^{5}$ Department of Respiratory Diseases, University of Marburg, Marburg, Germany

\subsection{6/thoraxjn-2015-207770.257}

Introduction Currently there is limited real-life data available regarding the distribution of COPD patients using the GOLD 2011 criteria. The German DACCORD registry that collects data from a large 'real life' population sample was used to categorise COPD patients according to GOLD 2011.

Methods To be eligible for entry into DACCORD, all patients had to have a diagnosis of COPD (consistent with the German Disease Management Programme definition), and, prior to entry, had to have either newly initiated bronchodilator maintenance medication, or to have a bronchodilator added to their maintenance regimen. No other inclusion criteria were applied, and the only exclusion criterion was a diagnosis of asthma. In primary and secondary care, data were collected from 4,123 COPD outpatients, including spirometry, exacerbations, CAT and mMRC. Results The mean age of patients was 65.7 years with $40.3 \%$ of patients still working and $73.3 \%$ patients with duration of disease $\geq 1$ year.

Based on mMRC $0-1,37.2 \%$ of patients had few symptoms (A and C); using CAT $<10$, only $9.0 \%$ were categorised into these two groups. $32.5 \%$ of the patients were assigned to $\mathrm{C}$ and D groups solely due to FEV1 $<50 \%$.

After 12 months, $41.4 \%$ patients in GOLD A were categorised in a higher GOLD category, while $42.7 \%$ of GOLD D patients were categorised in a lower GOLD category (GOLD categorization based on CAT). $67.6 \%$ of patients categorised as D at baseline due to exacerbation history alone were categorised as GOLD B after 1 year follow-up.

Almost $80 \%$ of GOLD B patients were still categorised as GOLD B after the observation period of 12 months and were therefore the most stable subgroup with regards to COPD severity according to GOLD 2011 (Figure 1).

\begin{tabular}{|c|c|c|c|c|c|c|c|}
\hline & \multicolumn{6}{|c|}{ GOLD 2011 at 12 months } \\
\hline & & A & B & C & $\mathrm{D}^{*}{ }^{*}$ & $\mathrm{D}^{*}{ }^{2}$ & D3* \\
\hline & $\begin{array}{r}\mathrm{N} \\
\text { (\% of total) }\end{array}$ & \begin{tabular}{|l|}
370 \\
$(9.4 \%)$
\end{tabular} & $\begin{array}{l}2144 \\
(54.3 \%)\end{array}$ & $\begin{array}{l}139 \\
(3.5 \%)\end{array}$ & $\begin{array}{l}936 \\
(23.7 \%)\end{array}$ & $\begin{array}{l}169 \\
(4.3 \%)\end{array}$ & $\begin{array}{l}169 \\
(4.3 \%)\end{array}$ \\
\hline A & $\begin{array}{l}\mathbf{2 3 2} \\
(5.9 \%)\end{array}$ & \begin{tabular}{|l|}
136 \\
$(3.4 \%)$
\end{tabular} & $\begin{array}{l}68 \\
(1.7 \%)\end{array}$ & $\begin{array}{l}16 \\
(<1 \%)\end{array}$ & $\begin{array}{l}7 \\
(<1 \%)\end{array}$ & $\begin{array}{l}2 \\
(<1 \%)\end{array}$ & $\begin{array}{l}2 \\
(<1 \%)\end{array}$ \\
\hline B & $\begin{array}{l}\mathbf{1 7 7 4} \\
(44.9 \%)\end{array}$ & \begin{tabular}{|l|}
142 \\
$(3.6 \%)$
\end{tabular} & $\begin{array}{l}1419 \\
(35,9 \% \%)\end{array}$ & $\begin{array}{l}15 \\
\text { (<1\%) }\end{array}$ & $\begin{array}{l}114 \\
(2.9 \%) \\
\end{array}$ & $\begin{array}{l}68 \\
(1.7 \%)\end{array}$ & $\begin{array}{l}17 \\
(<1 \%)\end{array}$ \\
\hline c & $\begin{array}{l}124 \\
(3.1 \%)\end{array}$ & \begin{tabular}{|l}
30 \\
$(<1 \%)$
\end{tabular} & $\begin{array}{l}14 \\
(<1 \%)\end{array}$ & \begin{tabular}{|l|}
39 \\
$(<1 \%)$
\end{tabular} & $\begin{array}{l}32 \\
(<1 \%)\end{array}$ & $\begin{array}{l}7 \\
(<1 \%)\end{array}$ & $\begin{array}{l}2 \\
(1 \%)\end{array}$ \\
\hline $\mathrm{D} 1^{*}$ & $\begin{array}{l}865 \\
(21.9 \%)\end{array}$ & \begin{tabular}{|l|}
33 \\
$(<1 \%)$ \\
\end{tabular} & $\begin{array}{l}176 \\
(4.5 \%) \\
\end{array}$ & $\begin{array}{l}42 \\
(1.0 \%) \\
\end{array}$ & $\begin{array}{l}553 \\
(14.0 \%) \\
\end{array}$ & $\begin{array}{l}5 \\
(<1 \%)\end{array}$ & $\begin{array}{l}59 \\
(1.5 \%) \\
\end{array}$ \\
\hline $\mathrm{D} 2 *$ & $\begin{array}{l}\mathbf{5 9 9} \\
(15.2 \%)\end{array}$ & \begin{tabular}{|l|}
32 \\
$(<1 \%)$
\end{tabular} & $\begin{array}{l}405 \\
(10.3 \%)\end{array}$ & $\begin{array}{l}12 \\
\text { (<1\%) }\end{array}$ & $\begin{array}{l}50 \\
(1.3 \%)\end{array}$ & $\begin{array}{l}76 \\
(1.9 \%)\end{array}$ & $\begin{array}{l}22 \\
(<1 \%)\end{array}$ \\
\hline D3* & $\begin{array}{l}355 \\
(9.0 \%)\end{array}$ & $\begin{array}{l}7 \\
(<1 \%)\end{array}$ & $\begin{array}{l}65 \\
(1.6 \%)\end{array}$ & $\begin{array}{l}15 \\
(<1 \%)\end{array}$ & $\begin{array}{l}181 \\
(4.5 \%)\end{array}$ & $\begin{array}{l}11 \\
(<1 \%)\end{array}$ & $\begin{array}{l}67 \\
(1.7 \%)\end{array}$ \\
\hline
\end{tabular}

Abstract P120 Figure 1
Conclusion A significant proportion of patients in the DACCORD registry are classified in GOLD C and D groups based solely on airflow limitation, in accordance with previous studies. Patients categorised as GOLD B were the most stable over the observational period of 12 months according to GOLD 2011. With the prospective collection of exacerbations over the second year of follow-up, a clearer picture of progression of GOLD 2011 categorisation might be drawn.

\section{P121 CHARACTERISTICS OF COPD PATIENTS WITH AND WITHOUT MAINTENANCE TREATMENT AT BASELINE, BY GOLD STAGE: TONADO}

${ }^{1} \mathrm{~S}$ Korn, ${ }^{2} \mathrm{R}$ Abrahams, ${ }^{3} \mathrm{~L}$ Grönke, ${ }^{4} \mathrm{~L}$ Korducki, ${ }^{3} \mathrm{VC}$ Amatto, ${ }^{1} \mathrm{R}$ Buhl. ${ }^{1}$ Pulmonary Department, Mainz University Hospital, Mainz, Germany; ${ }^{2}$ Morgantown Pulmonary Associates, Morgantown, West Virginia, USA; ${ }^{3}$ Boehringer Ingelheim Pharma GmbH \& Co. KG, Ingelheim, Germany; ${ }^{4}$ Boehringer Ingelheim Pharmaceuticals Inc., Ridgefield, Connecticut, USA

\subsection{6/thoraxjnl-2015-207770.258}

Rationale The efficacy and safety of the once-daily combination of tiotropium (T), a long-acting muscarinic antagonist (LAMA), and olodaterol $(\mathrm{O})$, a long-acting $\beta_{2}$-agonist (LABA), for the treatment of chronic obstructive pulmonary disease (COPD) has been established. We investigated whether there was a difference in the characteristics of COPD patients with and without baseline maintenance treatment.

Methods Two replicate, randomised, 52-week, double-blind, parallel-group, Phase III trials (NCT01431274; NCT01431287; n $=5162)$ assessed the efficacy and safety of once-daily treatment with $\mathrm{T}+\mathrm{O}\left(2.5 / 5 \mu \mathrm{g} ; 5 / 5 \mu \mathrm{g}\right.$; Respimat ${ }^{\circledR}$ inhaler $)$ compared to the individual components. Baseline characteristics of COPD patients within Global initiative for chronic Obstructive Lung Disease (GOLD) subgroups 2 and 3/4, with/without maintenance treatment (prior LABA, LAMA or both at baseline), are presented, based on data from the pooled set.

Results Most patients received baseline maintenance treatment (3037 vs 2121) and of those, there was a greater proportion of GOLD $3 / 4$ compared to GOLD 2 patients $(52.58 \%$ vs $47.42 \%$, respectively). An opposite trend was observed in patients not receiving maintenance treatment (GOLD 3/4, 45.87\% vs GOLD 2, 54.13\%). The proportion of current smokers was lower in GOLD 3/4 than GOLD 2 patients, as expected (Table); nevertheless, irrespective of GOLD stage, there was a greater proportion of smokers without maintenance treatment than with maintenance treatment $(42.81 \%$ vs $32.86 \%$, respectively). As expected, pulmonary function was reduced in GOLD 3/4 compared to GOLD 2 patients, although it appeared comparable between patients with and without maintenance treatment. Of the patients with maintenance treatment, a considerably greater proportion received inhaled steroids compared to those without prior LAMA/LABA treatment $(69.67 \%$ vs $15.51 \%$, respectively). Furthermore, a smaller proportion of patients without prior LAMA/LABA treatment received short-acting $\beta$-adrenergics compared to those with maintenance treatment (Table 1). Of the GOLD 3/4 patients without baseline maintenance treatment, $43.4 \%$ were not receiving any other pulmonary medication. 